\title{
Sabanci University launches Industrial PhD programme in Action Research
}

\section{Richard Ennals ${ }^{1}$}

Published online: 9 January 2020

(c) Springer-Verlag London Ltd., part of Springer Nature 2020

Sabanci University in Turkey, with the support of an experienced international faculty team, have launched a new Industrial $\mathrm{PhD}$ programme in Action Research. Teaching on the full programme will begin in autumn 2020, following an introductory semester from February 2020.

Sabanci University began teaching in 1999, after foundation through an Action Research process led by Prof Oguz Baburoglu. He is now ARAMA chair at Sabanci Business School. Sabanci University has received numerous awards for innovation and entrepreneurship in recent years.

Students will be in continued employment in senior executive roles, with their studies focused on individual and joint transformation projects. They will take a number of $42-\mathrm{h}$ courses, with international faculty contributing in person and online. For the first time, the programme brings together diverse traditions in the global Action Research community, including Search (Trist and Emery). Emancipatory Action Research (Freire and Fals Borda), Democratic Dialogue and Development (Gustavsen), Participatory Action Research, and Insider Action Research.

There are opportunities for "Special Students" to take individual courses, rather than registering for the full $\mathrm{PhD}$.
For further information, including the Course Catalogue, contact baburoglu@ sabanciuniv.edu.

Contact author: Richard Ennals

Emeritus Professor, Kingston University, Kingston Upon Thames, UK

Editorial Advisory Board, AI \& Society

Email: richard.ennals@gmail.com

International Faculty Member

Sabanci University Industrial PhD Action Research Program

Adjunct Professor, University of Agder, Norway

Adjunct Professor, Norwegian University of Science and Technology

Editor in Chief, European Journal of Workplace Innovation

Co-Editor, International Journal of Action Research

Publisher's Note Springer Nature remains neutral with regard to jurisdictional claims in published maps and institutional affiliations.
Richard Ennals

richard.ennals@gmail.com

1 Kingston University, Kingston Upon Thames, London, UK 